\title{
The Effects of Production Parameters on The Physical Properties of Dual-Core Slub Yarns
}

\author{
Hüseyin Gazi Türksoy ${ }^{1}$, Münevver Ertek Avcı $^{2}$, Nida Yıldırım ${ }^{3 *}$ \\ ${ }^{1}$ Erciyes University, Department of Textile Engineering, Kayseri, Turkey. \\ ${ }^{2}$ Malatya Turgut Ozal University, Yesilyurt Vocational School, Malatya, Turkey. \\ ${ }^{3}$ Karadeniz Technical University, Trabzon Vocational School, Trabzon, Turkey.
}

Corresponding Author: Nida YILDIRIM, nidayildirim@ktu.edu.tr

\begin{abstract}
Denim is fabric construction which is popular worldwide with its fit, ease and durability and it has evolved significantly in terms of aesthetic and functional properties throughout time to maintain this popularity. Denim fabric manufacturers are in search of different visual and functional properties at all times. In this study, dual-core slub yarns were developed for using as weft yarn in denim fabric structure. Dual-core and slub production techniques were used simultaneously for production of dualcore slub yarns which will use improving elastic and aesthetic features of denim fabrics. Within the scope of the scientific study, firstly dual-core slub yarn samples called Group-I were produced with different core draft values of EME (Elastomultiester-I.core) and elastane (II.core). The effects of cores' draft ratio on the features of dual-core slub yarns such as unevenness, hairiness, tenacity and breaking elongation were investigated with Group-I yarn samples. The breaking elongation values are affected by both EME and elastane core draft factors, while the tenacity is only affected by EME core draft factor. Moreover, in order to examine the effects of slub types, the physical properties of the dual-core slub yarn selected from Group I, were compared with equivalent dual-core yarns (having two different version of basic slub and without slub) which called Group II. The results showed that slub types have statistically insignificant effect on the hairiness, tenacity and breaking elongation
\end{abstract}

\section{ARTICLE HISTORY}

Received: 30.04.2019

Accepted: 24.07.2020

\section{KEYWORDS}

Dual-core, slub yarn, denim fabric.

\section{INTRODUCTION}

Core-spun yarn, one of the novel materials, generally use in the direction of weft and/or warp to improve elastic comfort properties of denim fabrics. It is desirable that the elasticity value is high in denim fabrics and the permanent elongation value is low. Using of core-spun yarn, having just an elastane core in fabric, can be caused permanent elongation problem [1]. The permanent elongation that encountered during use of garment, arises as a result of long-term and continual forces and induces bagging problems at some sections of the garments such as knees, pockets, elbows, heel and hips. Furthermore, using as warp of core-spun yarn, having just an elastane core, can also be problematic during weaving processes [2]. Dual-core yarn production method as an advanced version of the core-spun technique was developed in order to overcome these kinds of problems [3]. In dual-core production method, two core filaments (one of them is elastane filament) are fed into the center of sheath fibers [4]. Using of some filaments such as T $400 \AA$, PBT, PET besides elastane core (as second core), in the dual-core yarns not only prevents some problems that can be occurred during weaving process, but also reduces the permanent elongation values considerably. In another words, using dual-core yarns in denim fabric structures, enables the production of high quality denim fabrics.

Several publications about the dual-core spun yarns have been found out, and the publications have been summarized below. Jabbar et al. [5] concluded that cores with the higher linear densities caused the lower tenacity, lower unevenness

To cite this article: Türksoy HG, Ertek Avcı M, Yıldırım N. 2020. The effects of production parameters on the physical properties of dual-core slub yarns. Tekstil ve Konfeksiyon, 30(3), 165-172. 
and higher hairiness values of dual-core-spun cotton yarns. In addition, it was founded that increasing of polyester denier had decreasing effect on yarn imperfection.

Ertaş et al. [6] investigated the denim fabrics woven with the dual-core weft yarn (sheath-cotton fiber and corespolyester and elastane filament) in various densities. They concluded that as weft density increases, elasticity and permanent elongation values decrease.

In the study performed by Babaarslan et al. [7] Co/PET/ Elastane dual core-spun weft yarns with different elastane drafts were produced in order to investigate the effect of fineness of filament and draft of elastane on denim fabric features. At the end of the study, it was reported that they are effective factors on tear force, breaking force, breaking elongation, elastic recovery, water absorption rate and vertical wicking rate.

Tantawy et al. [8] evaluated the effects of different types of weft yarns on the pilling performances of jeans. Core spun yarn, dual-core spun yarn without welding and dual-core spun yarn with welding were produced in the study. It was found that the both dual-core yarn types with higher yarn number have lower pilling values.

The aim of the study performed by Türksoy and Yıldırım [9] was to investigate the effect of some production parameters on the features of dual-core yarns (sheath-cotton fiber, coreswool fiber and elastane filament). Experimental results showed that unevenness and hairiness values decrease as twist level increases. In addition, it was found that the tenacity values of yarns increase with higher elastane draft and twist level. Furthermore, the study revealed that the elongation values increase when wool draft value of dualcore yarns increases. Furthermore, Türksoy et al. [10] searched the effect of production methods (pretreated dualcore and dual-core yarns) on yarn features.
In the paper performed by Bedez Ute [1], elastane (EL), elastomultiester (EME) and poly butylene terefthalate (PBT) were used as core in dual-core yarns and these dualcore yarns were used as weft yarns in weaving. Then, the effect of the weft yarn composition and weft density on denim fabric properties was examined.

Fancy yarns, which offer the opportunities to designers for creating new fashionable effects and styles, are also used in denim fabric structures. Slub yarns, one of fancy yarn types, can be defined as yarns that has been purposely spun with slubs (thicker sections along the yarn) with the intention of giving the fabric an organic, tactile look and feel. Even though, unevenness of yarns was generally regarded as damaged or of poor quality, using slub yarns as a fancy yarns in denim fabrics became a trend due to the original and aesthetic value of the slub effect. Parameters representing the structure of slub yarns are slub thickness, slub distance $(\mathrm{mm})$, slub length $(\mathrm{mm})$, and count of slubs per unit length (Figure 1).

Modified ring spinning frames in which drafting system can be intermittent accelerated are most commonly machines for the production of different slub yarns. It is possible to examine the slub yarns produced in ring spinning machines in three main groups as basic slub, multi-twist slub and multi-count slub. The basic slub yarns are yarn types that the twist is not changed, but the yarn count is changed at regular intervals (Figure 2a). Opposite to the basic slub yarn, multi-twist slub yarns haven't count variations, but only a twist variation (Figure 2b). On the other hand, in the multi-count slub yarn structures, both yarn count and twist value changes at certain intervals along the length of the yarn (Figure 2c). In addition, the multi-effect slub yarns which are the combination of these three slub types can also be produced.

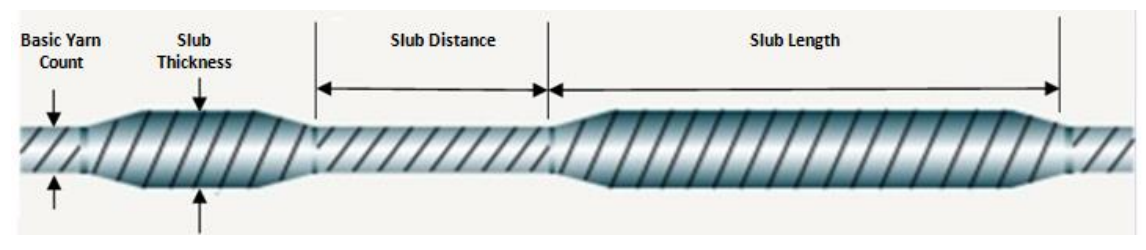

Figure 1. The parameters of slub yarn.

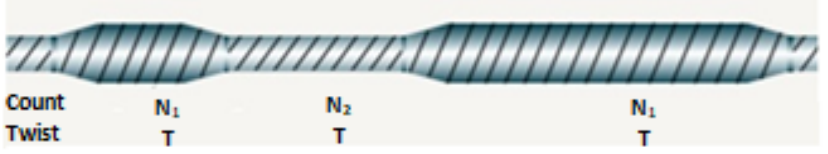

a)

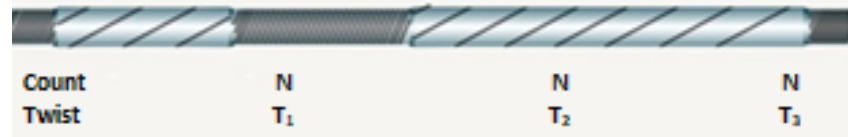

b)

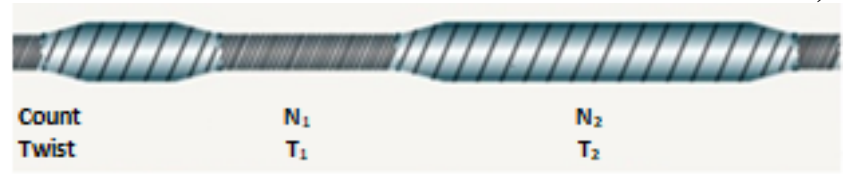

c)

Figure 2. Basic slub (a), Multi-twist slub (b), Multi-count slub (c). 
In earlier research on slub yarn, Özgen and Altaş [11] researched the effect of slub yarn structure on air permeability of twill $1 / 3$ fabrics by using Taguchi L9 orthogonal design. It was found that slub distance is the least effective parameter, amplitude of slub is the most important parameter on air permeability value. In addition, they investigated effects of slub yarn parameters such as slub distance, slub length, yarn linear density and slub thickness on the fabric abrasion by using Taguchi L9 orthogonal design. It was concluded that the raise in the slub length and slub thickness raises the abrasion resistance, and slub distance also is a less effective parameter on abrasion of the fabrics [12].

Ilhan et al. [13] studied effects of slub distance, slub multiplier, slub length, yarn count, twist coefficient, ramp time parameters on the elongation and breaking force of slub yarns. It was concluded that while the slub length, slub distance, and base yarn count are statistically significant for the breaking force of slub yarn, the slub multiplier, base yarn count and twist coefficient have an effect on the breaking elongation. Within the scope of this study, dualcore and slub production techniques were used simultaneously for production of innovative dual-core slub yarns which will use improving elastic and aesthetic properties of denim fabrics.

\section{MATERIAL AND METHOD}

In the study, firstly dual-core slub yarn samples called Group-I were produced with different draft values of EME (Elastomultiester-I.core) and elastane (II.core). The effects of cores' draft ratio on the features of dual-core slub yarns such as unevenness, hairiness, tenacity and breaking elongation were investigated with Group-I yarn samples. Moreover, in order to examine the effects of slub types, the physical properties of the dual-core slub yarn selected from Group I, were compared with equivalent dual-core yarns (having two different version of basic slub and without slub) which called Group II.

\subsection{Material}

In the present study, eleven different types of dual-core basic slub yarns with different basic slub types, different EME (T400®) draft values and different elastane draft values were produced. Dual-core yarn samples without slub were also produced as a control group. The count of dualcore slub yarn samples was $\mathrm{Ne} 10,4 / 1$. 55 dtex T400® and 78 dtex elastane were used as core components. Elongation of T400 fibers from elastomultiester fibers with high recovery property used as core in yarn samples, is $15-22 \%$ and its tenacity is 4-4.5 gf/denier. Cotton fibers used as sheath fiber have 80.2 uniformity index, $28.19 \mathrm{~mm}$ length, $5.8 \%$ elongation, fineness of 4.55 microner and $31.27 \mathrm{~g} / \mathrm{tex}$ tenacity.

\subsection{Method}

The yarn samples were spun on the Marzoli MDS1 ring spinning machine modified with Pinter dual-core and Marzoli slub system. In the production of dual-core yarns, the core parts are fed to the center of the yarn separately in the modified ring machine. The schematic view of the dual-core manufacturing method and image of ring machine modified for dual-core are showed in Figure 3.

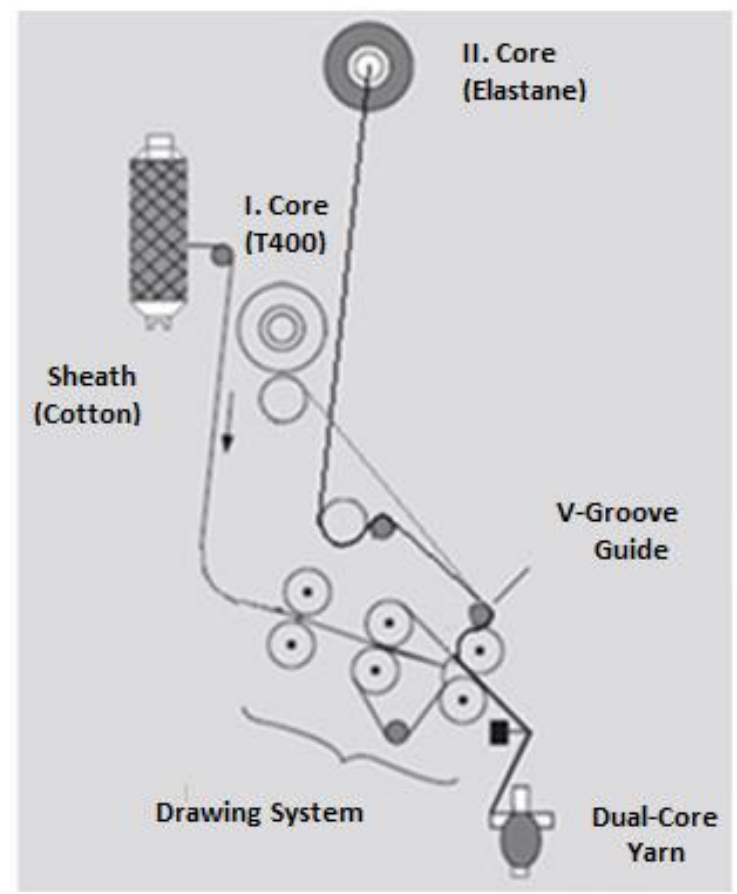

(a)

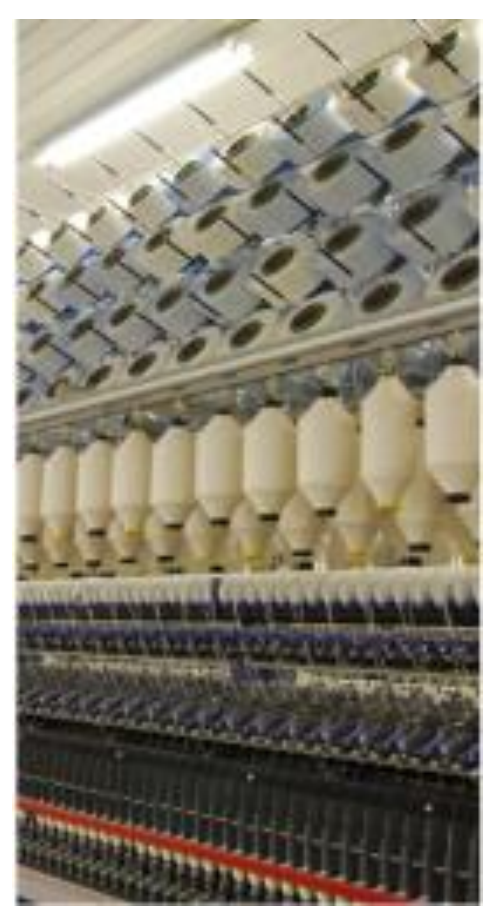

(b)

Figure 3. Production principle of dual-core yarn (a) and machine image (b). 
The production parameters of the yarns are summarized in Table 1. Spindle speed of ring frame is $8500 \mathrm{rpm}$ and the twist coefficient of yarn samples is 4,4 ae. Dual-core basic slub yarns were coded as 'DCS' and dual-core yarns without slub were coded as 'DC'.

In the manufacturing of dual-core basic slub yarn, while spinning the dual-core yarn with certain yarn number and twist level in the ring spinning machine, the speed of rotation of the middle and rear draft shafts are accelerated suddenly at desired time intervals, by unchanging the speed of the front draft shaft. Thus, instant draft is reduced and thicker places are formed in the dual-core yarn. The parameters of basic slub types are seen in Table 2 .

The technical visuals (simulative images of fabrics) created with the Amsler WinPK® II EP5000 program of the yarns produced by the ring spinning system were given in Figure 4 in order to see visual effects of these yarns on the fabric surface.

In the study, firstly, samples were conditioned according to TS EN ISO 139 standard. Then, unevenness and hairiness values were measured by Uster Tester 5 device. Furthermore, the tenacity and breaking elongation were measured by Uster Tensorapid 4 Tester, according to relevant standard.

Test results of Group-I yarns were analyzed by using twoway replicated analysis of variance (ANOVA) and test results of Group-II yarns were analyzed by using one-way replicated analysis of variance (ANOVA). The means of results were also contrasted by DUNCAN tests by using SPSS version 13.0.

\section{RESULTS AND DISCUSSION}

In this part, the various physical properties of Group I and Group II yarns were evaluated. The average test results of Group-I and Group-II yarns are seen in Table 3.

Unevenness values of the Group-I dual-core slub yarns can be seen in Figure 5. According to the ANOVA results; EME draft $\left(p_{p}=0.16\right)$, elastane draft $\left(p_{e}=0.66\right)$ and the intersection of these factors $\left(p_{p x e}=0.21\right)$ were found to be statistically insignificant on unevenness values.

The unevenness values of Group-II yarn samples can be seen in Figure 6. According to the ANOVA results; the slub types have statistically significant effect on unevenness values of Group-II yarn samples $\left(\mathrm{p}_{\mathrm{s}}=0.00\right)$.

Table 1. Production parameters of yarn samples.

\begin{tabular}{lcccc}
\hline $\begin{array}{c}\text { Yarn } \\
\text { Groups }\end{array}$ & Yarn Samples & $\begin{array}{c}\text { I. Component } \\
\text { (EME) Draft }\end{array}$ & $\begin{array}{c}\text { II. Component } \\
\text { (Elastane) Draft }\end{array}$ & Type of Slub \\
\hline \multirow{6}{*}{ DCSA-1 } & 1.02 & 3.2 & \\
& DCSA-2 & 1.02 & 3.5 & \\
& DCSA-3 & 1.02 & 3.8 & \\
& DCSA-4 & 1.06 & 3.2 & (Slub A) \\
Group I & DCSA-5 & 1.06 & 3.5 & \\
& DCSA-6 & 1.06 & 3.8 & \\
& DCSA-7 & 1.1 & 3.2 & \\
& DCSA-8 & 1.1 & 3.5 & - \\
& DCSA-9 & 1.1 & 3.8 & (Slub B) \\
& & & 3.5 & (Slub C) \\
\hline
\end{tabular}

Table 2. Production parameters of basic slub types.

\begin{tabular}{|c|c|c|c|}
\hline Parameters & Slub A & Slub B & Slub C \\
\hline The number of slubs per unit length $(100 \mathrm{~m})$ & 169 Slub & 284 Slub & 83 Slub \\
\hline Slub Length & $3 \mathrm{~cm}$ & $6 \mathrm{~cm}$ & $25-42,5 \mathrm{~cm}$ \\
\hline $\begin{array}{l}\text { Slub Thickness } \\
\text { Slub Distance }\end{array}$ & $\begin{array}{c}1,35 \text { Layer } * \text { Nominal count } \\
29-80 \mathrm{~cm}\end{array}$ & $\begin{array}{c}\text { 1,46 Layer*Nominal count } \\
10-50 \mathrm{~cm}\end{array}$ & $\begin{array}{c}1,25 \text { and } 1,34 \text { Layer* Nominal count } \\
40-140 \mathrm{~cm}\end{array}$ \\
\hline
\end{tabular}

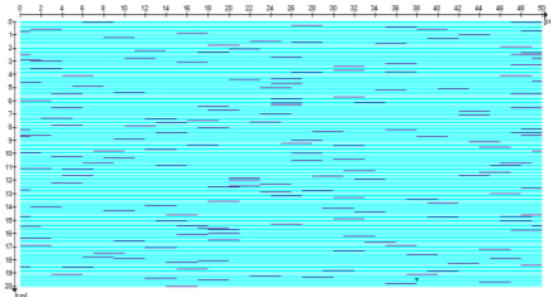

$\mathbf{A}$

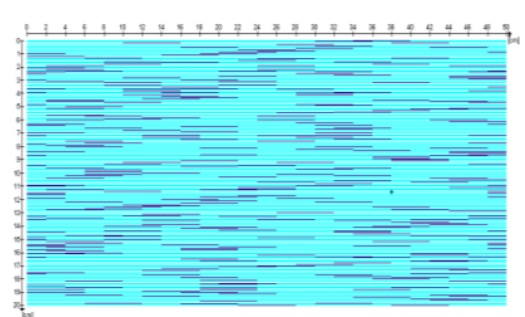

B

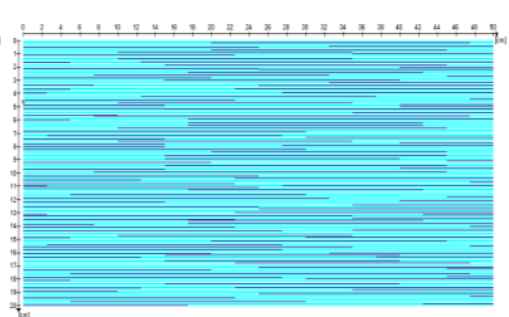

C

Figure 4. Simulative images of fabrics for Slub A, Slub B and Slub C. 
Table 3. The average test results of Group-I and Group-II yarns.

\begin{tabular}{ccccc}
\hline $\begin{array}{c}\text { Yarn } \\
\text { Code }\end{array}$ & $\begin{array}{c}\text { Unevenness } \\
\mathbf{( \% )}\end{array}$ & $\begin{array}{c}\text { Hairiness } \\
\mathbf{( H )}\end{array}$ & $\begin{array}{c}\text { Tenacity } \\
\mathbf{( C N / t e x )}\end{array}$ & $\begin{array}{c}\text { Breaking } \\
\text { Elongation (\%) }\end{array}$ \\
\hline DCSA-1 & 13,45 & 7,5 & 15,75 & 7,95 \\
DCSA-2 & 13,34 & 7,47 & 16,42 & 8,34 \\
DCSA-3 & 13,49 & 7,49 & 16,58 & 8,5 \\
DCSA-4 & 13,6 & 7,41 & 16,83 & 8,77 \\
DCSA-5 & 13,59 & 7,89 & 16,96 & 9,04 \\
DCSA-6 & 13,9 & 7,77 & 16,95 & 9,36 \\
DCSA-7 & 13,66 & 7,72 & 17,04 & 9,96 \\
DCSA-8 & 13,81 & 7,62 & 16,93 & 10,44 \\
DCSA-9 & 13,73 & 7,76 & 17,16 & 10,4 \\
DC & 11,33 & 8,51 & 16,48 & 9,87 \\
DCSB & 19,86 & 9,05 & 16,03 & 9,85 \\
DCSC & 16,27 & 8,74 & 16,17 & 10,22 \\
\hline
\end{tabular}

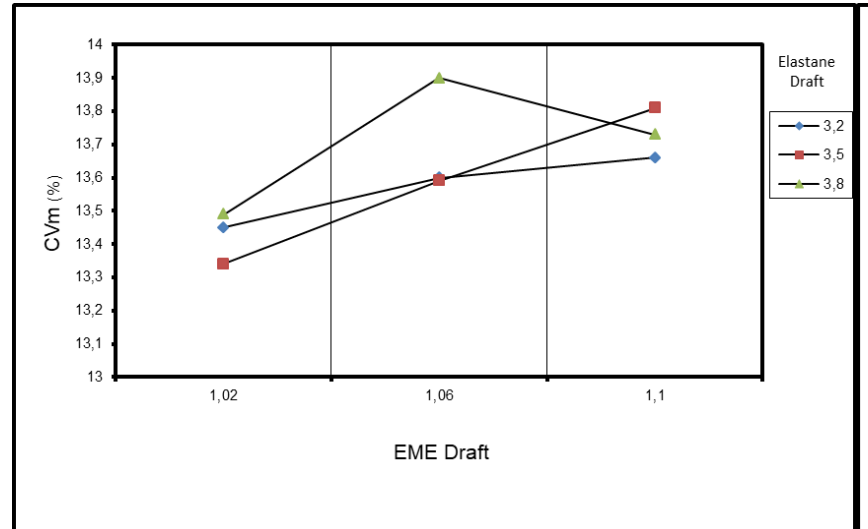

Figure 5. The average unevenness results of Group-I yarn samples.

According to DUNCAN test results showed in Table 4, the difference between unevenness values of yarns for all slub types is statistically significant. When the samples DC and dual-core slub yarns compared in terms of unevenness properties, unevenness values of DC were found to be significantly lower than that of dual-core slub yarns, as expected. Because of the highest slub thickness and the number of slubs per unit length, DCSB yarn type have showed the highest unevenness value.

Hairiness values of the Group-I and Group-II dual-core slub yarns are presented respectively in Figure 7 and 8. When the effect of draft factors on hairiness is examined, according to the ANOVA results; EME draft $\left(p_{p}=0.27\right)$, elastane draft $\left(\mathrm{p}_{\mathrm{e}}=0.61\right)$ and the intersection of these factors ( $\mathrm{p}_{\mathrm{pxe}}=0.51$ ) were found to be statistically insignificant on hairiness values of Group-I yarn samples. Moreover, according to the ANOVA results; the slub types have statistically insignificant effect on hairiness values of Group-II yarn samples $\left(\mathrm{p}_{\mathrm{s}}=0.19\right)$. Yarn hairiness correlates a close correlation with unevenness and slub parts show more hairiness than base yarn, because there are more fibers in its cross section. [14]. However, in this study, while slub type has a statistically significant effect on unevenness, it have an insignificant effect on hairiness.

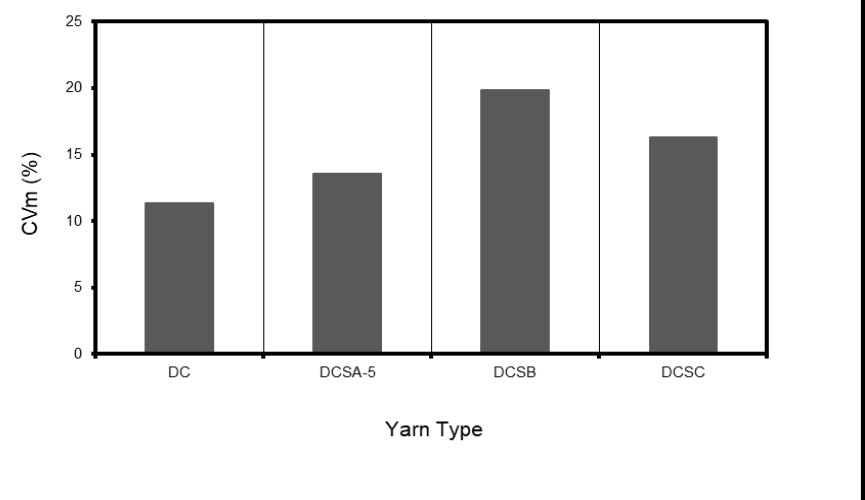

Figure 6. The average unevenness results of Group-II yarn samples.

The tenacity values of Group-I yarn samples can be seen in Figure 9. According to the ANOVA results; EME draft values have statistically significant on the tenacity values of Group-I yarn samples $\left(\mathrm{p}_{\mathrm{p}}=0.01\right)$, while elastane draft values $\left(p_{e}=0.40\right)$ and the intersection of factors $\left(p_{p x e}=0.71\right)$ were found to be statistically insignificant on tenacity values of Group-I yarn samples.

In DUNCAN test results showed in Table 5, it is seen that the difference between tenacity values for 1.02 EME draft and the other EME drafts is statistically significant. It is found out that tenacity values of yarn samples have an increasing trend, while EME draft is increasing.

Table 4. DUNCAN test results for unevenness values of Group-II yarn samples.

\begin{tabular}{cccccc}
\hline Process & S & \multicolumn{4}{c}{ Subset } \\
\hline Yarn Type & & $\mathbf{1}$ & $\mathbf{2}$ & $\mathbf{3}$ & $\mathbf{4}$ \\
DC & 5 & 11.33 & & & \\
DCSA-5 & 5 & & 13.87 & & \\
DCSC & 5 & & & 16.27 & \\
DCSB & 5 & & & & 19.86 \\
Sig. & & 1.00 & 1.00 & 1.00 & 1.00 \\
\hline
\end{tabular}




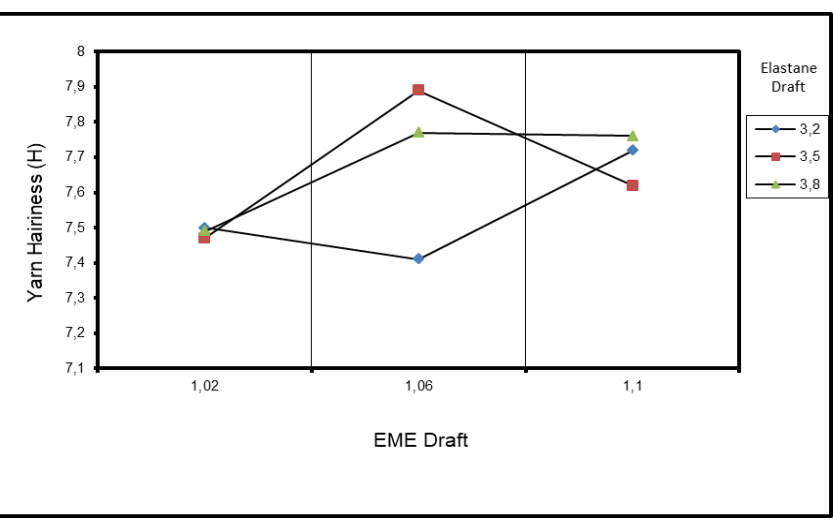

Figure 7. The average hairiness results of Group-I yarn samples.

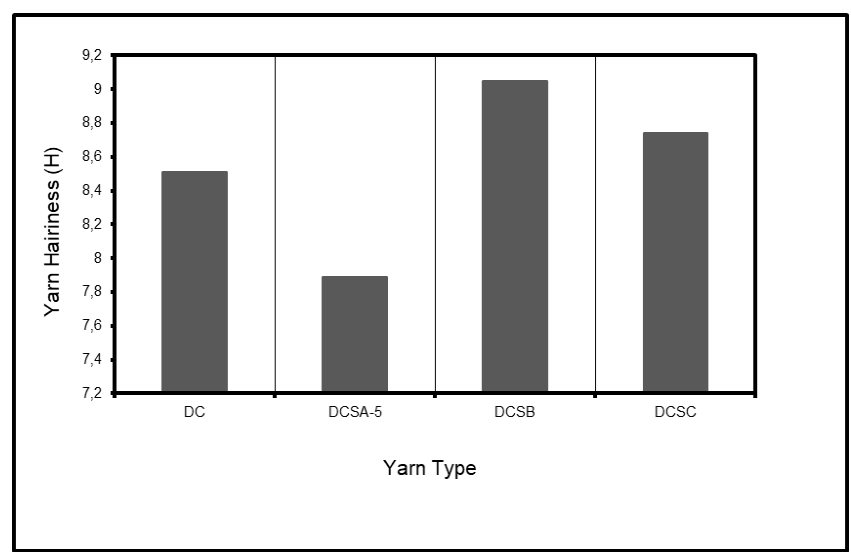

Figure 8 . The average hairiness results of Group-II yarn samples.

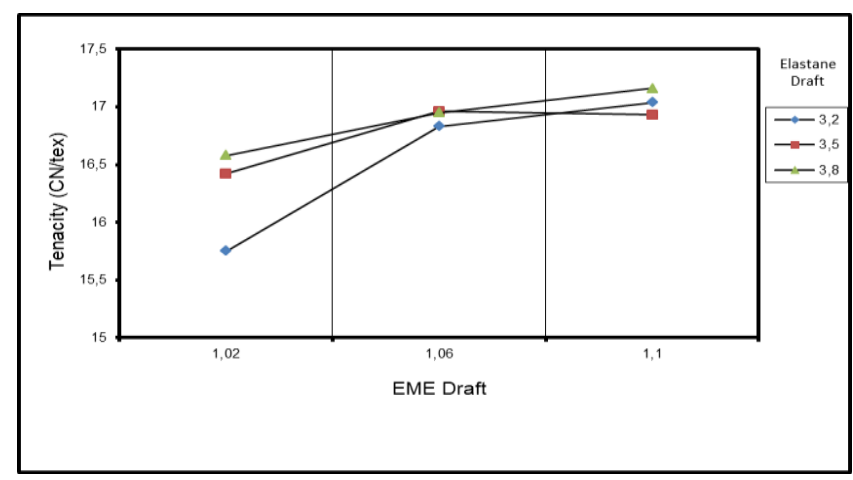

Figure 9. The average tenacity results of Group-I yarn samples.

The tenacity values of Group-II yarn samples can be seen in Figure 10. The weak points which may occur at the beginning or end of slubs, have an reducing effect on slub yarn strength [13]. However, when the effect of slub types on tenacity is examined, according to the ANOVA results; slub types were found to be statistically insignificant on tenacity values of Group-II yarn samples $\left(\mathrm{p}_{\mathrm{s}}=0.53\right)$.

Table 5. DUNCAN test results for tenacity values of Group-I yarn samples.

\begin{tabular}{cccc}
\hline Process & S & \multicolumn{2}{c}{ Subset } \\
\hline EME Draft & & 1 & 2 \\
1.02 & 15 & 16.25 & \\
1.06 & 15 & & 16.91 \\
1.1 & 15 & & 17.04 \\
Sig. & & 1.00 & 0.63 \\
\hline
\end{tabular}


insignificant on breaking elongation values of Group-II yarn samples $\left(\mathrm{p}_{\mathrm{s}}=0.65\right)$.

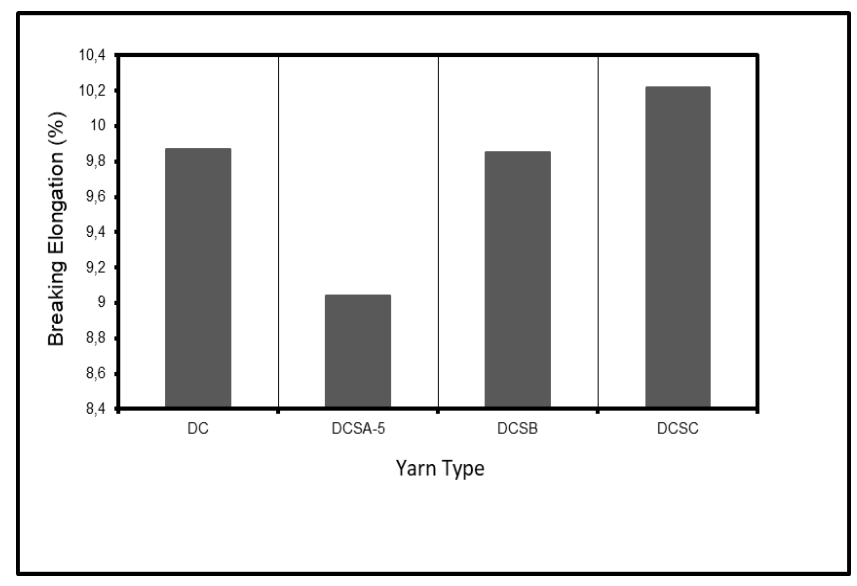

Figure 12. The average breaking elongation results of Group-II yarns.

Table 6. DUNCAN results for breaking elongation values of Group-I yarns.

\begin{tabular}{ccccc}
\hline Process & S & \multicolumn{3}{c}{ Subset } \\
\cline { 1 - 5 } EME Draft & & $\mathbf{1}$ & $\mathbf{2}$ & $\mathbf{3}$ \\
\hline 1.02 & 15 & 8.26 & & \\
1.06 & 15 & & 9.06 & 10.27 \\
1.1 & 15 & & & 1.00 \\
Sig. & & 1.00 & 1.00 & \\
\hline Elastane Draft & & & & \\
\hline 3.2 & 15 & 8.89 & & \\
3.5 & 15 & & 9.28 & \\
3.8 & 15 & & 9.42 & \\
Sig. & & 1.00 & 0.22 & \\
\hline
\end{tabular}

\section{CONCLUSION}

In this study, dual-core slub yarns produced with different EME (Elastomultiester-I. core) draft and elastane (II.core) draft values are called Group-I. The influences of EME and elastane draft on the features such as hairiness, unevenness, breaking elongation and tenacity of yarns were investigated with these yarn samples. Moreover, in order to examine the effects of slub types, the physical features of the dual-core slub yarn type selected from Group I were evaluated comparatively with equivalent dual-core yarns (having two different version of basic slub and without slub) which called Group II.

When physical properties of dual-core basic slub yarns (Group-I) produced with different elastane draft and EME draft values were examined; it was observed that draft values were have statistically insignificant effect on unevenness and hairiness. While the tenacity values of yarns are only affected by EME draft factor, the breaking elongation of yarns are affected by EME draft and elastane draft factors. In addition, it is seen that the breaking elongation values of yarns increase with increase in the EME draft value.

Basic slub types were found to be significant on the only unevenness values, when properties of dual-core slub yarns (Group-II) produced with different basic slub types were investigated. According to statistical analysis; a significant difference between the unevenness values for all types of yarns was found, and unevenness values of dual-core yarns without slub were found to be significantly lower than that of the others, as expected. The hairiness, tenacity and breaking elongation values of the dual-core slub yarns produced in the study do not differ statistically, compared with dual-core yarn the samples without slub. In the light of these results, it is thought that innovative dual-core slub yarns can be used in denim fabrics construction, like dualcore yarns without slub.

In present study, dual-core and slub production techniques were used simultaneously for production of dual-core slub yarns which will use improving elastic and aesthetic properties of denim fabrics and properties of these yarns is investigated. In addition to this work, it is planned that the detailed studies on the performances of the dual-core slub yarns as weft yarn in denim fabric can be conducted in the future.

\section{REFERENCES}

1. Ute, T. B., 2018. Analysis of mechanical and dimensional properties of the denim fabrics produced with double-core and core-spun weft yarns with different weft densities. The Journal of The Textile Institute, DOI: 10.1080/00405000.2018.1470451.

2. Özdil, N., 2008. Stretch and bagging properties of denim fabrics containing different rates of spandex. Fibres \& Textiles in Eastern Europe, 16(66), 63-67.

3. Zhang, H., Xue, Y., Wang, S., 2006. Effect of filament over-feed ratio on surface structure of rotor-spun composite yarns. Textile Research Journal, 76(12), 922-923.

4. Paul, R. . (Ed.), 2015. Denim manufacture, finishing and applications, The Textile Institute Woodhead Publishing Limited, Cambridge, UK.

5. Jabbar, A., Tariq, U., Hussain, T., Basit, A., Hai, A., and Zubair, M., 2018. Effect of polyester and elastane linear density on the physical and mechanical properties of dual-core-spun cotton yarns, Journal of Natural Fibers, DOI: 10.1080/15440478.2018.1500338.

6. Ertaş O.G., Zervent Ünal B., Çelik N., 2016. Analyzing the effect of the elastane-containing dual-core weft yarn density on the denim fabric performance properties, The Journal of The Textile Institute,107(1),116-126.

7. Babaarslan O., Sarioğlu E., Çelik H.İ, Ertek Avcı, M., 2018. Denim fabrics woven with dual core-spun yarns, In book: Engineered Fabrics.

8. Tantawy, S.E., Sabry, M. and Bakry, M. 2017. The effect of different weft yarn production technique on the pilling property of jeans fabrics, International Design Journal, 7(3),161-169.

9. Türksoy, H.G., Yildırım, N., 2018. Effect of process variables on the properties of dual-core yarns containing wool/elastane, Industria Textile, 69 (5), 352-356.

10. Türksoy H.G, Kılıç G., Üstüntağ S., Yılmaz D., 2018. A comparative study on properties of dual-core yarns, The Journal of The Textile Institute, doi: 10.1080/00405000.2018.1534541. 
11. Özgen, B., Altaş, S., 2017. Evaluation of air permeability of fabrics woven with slub yarns, Tekstil ve Konfeksiyon, 27(2), 126-130.

12. Altaş, S., Ozgen, B., 2015. The effect of slub yarn descriptive parameters and yarn linear density on upholstery fabric abrasion resistance, The Journal of The Textile Institute, 107:10, 1232-1239, DOI: $10.1080 / 00405000.2015 .1100414$

13. İlhan İ, Babaarslan O, Vuruşkan D. 2012. Effect of descriptive parameters of slub yarn on strength and elongation properties, Fibres \& Textiles in Eastern Europe, 3(92): 33-38.

14. Mahmood, N., Arshad, M., Iftikhar, M., and Mahmood, T., 2009. Technological study of ring and compact spinning systems for the manufacturing of slub fancy yarn under multiple slub variations and its effect on woven fabric, Pakistan Journal of Agricultural Sciences, 46(2):124-129.

15. Kakvan A., Najar SS., Saidi RG., Namil M., (2007). Effects of draw ratio and elastic core yarn positioning on physical properties of elastic wool/polyester core-spun ring yarns. Journal of the Textile Institute, vol. 98, 57-63. DOI: 10.1533/joti.2005.0194.

16. Dhouib AB., El-Ghezal S., Cheikhrouhou M., 2006. A study of the impact of elastane ratio on mechanical properties of cotton wrapped elastane-core spun yarns, Journal of the Textile Institute, vol. 97, 167172. DOI: 10.1533/joti.2005.0121.7.

17. Gharahaghaji, AA., Zargar, E.N., Ghane, M., and Hossaini, A., 2009. Cluster-spun yarn - A new concept in composite yarn spinning, Textile Research Journal, 80(1): 19-24 DOI $10.1177 / 0040517508099916$. 